\title{
A twist in the tale: epiploic appendagitis mimicking acute appendicitis
}

\author{
Adrian Matthew Shields, ${ }^{1}$ Harry Dean, ${ }^{2}$ Simon Atkinson ${ }^{2}$
}

'Department of Medicine, St Thomas' Hospital, London, UK

'Department of Surgery, St Thomas' Hospital, London, UK

\section{Correspondence to}

Dr Adrian Matthew Shields, Department of Surgery, St Thomas' Hospital, London UK adrianshields@doctors.org.uk

Accepted 8 May 2014

\section{CrossMark}

To cite: Shields AM Dean H, Atkinson S. BMJ Case Rep Published online: [please include Day Month Year] doi:10.1136/bcr-2013203055

\section{DESCRIPTION}

A 38 -year-old woman with a history of endometrosis presented to hospital with a $24 \mathrm{~h}$ history of severe, stabbing right iliac fossa pain. On examination she was non-feverish and systemically well. Rebound tenderness was noted in the right iliac fossa without guarding. Urinanalysis was positive for leucocytes but blood tests were unremarkable with the exception of a $\mathrm{C}$ reactive protein of 7 .

CT of the abdomen was performed to elucidate the cause of her abdominal pain (figure 1). The CT revealed a $1.7 \mathrm{~cm}$ soft tissue nodule lying within the mesenteric fat anterior to the caecum with associated fat stranding. The appendix was seen to arise from the medial caecum and was not inflamed. The remaining viscera were of normal radiological appearance. A diagnosis of epiploic appendagitis was made.

The epiploic appendages are pedunculated, fatfilled outpouchings of the colon, averaging $3 \mathrm{~cm}$ in length. Epiploic appendagitis arises from torsion, ischaemia or haemorrhagic infarction of the epiploic appendages. Clinically, epiploic appendagitis presents as acute, localised abdominal pain without systemic symptoms. The diagnosis is typically made incidentally when CT is used to exclude other intra-abdominal pathologies. ${ }^{1}$

Epiploic appendages are not normally seen on CT. However, when inflamed they can appear as pericolic, fat density, oval lesions with surrounding inflammation. Occasionally, a central highattenuation dot is visible representing haemorrhage. Fat stranding is generally more pronounced than adjacent colonic wall thickening. Right-sided or caecal appendagitis is comparatively rare with most presentations arising from the sigmoid colon, mimicking diverticulitis. ${ }^{2}$

The patient was managed conservatively and made a complete recovery.
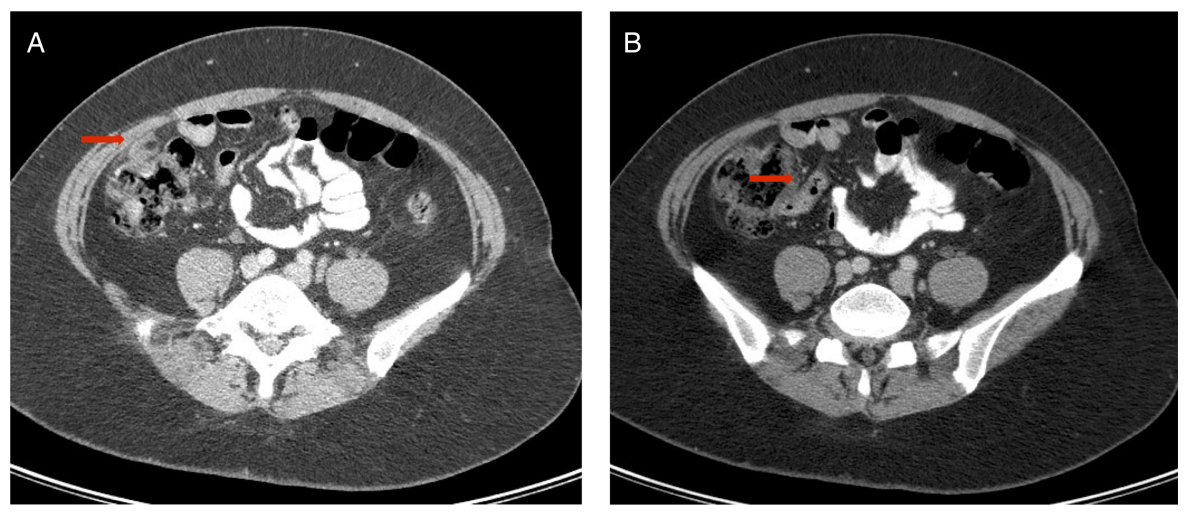

Figure 1 Axial CT of the abdomen performed on day 2 of admission. A fat density, $1.7 \mathrm{~cm}$ nodule can be seen overlying the anterior caecum with associated fat stranding corresponding to an inflamed epiploic appendage (A). The appendix is of normal radiological appearance and arises from the medial caecum (B). 


\section{Images in...}

Copyright 2014 BMJ Publishing Group. All rights reserved. For permission to reuse any of this content visit http://group.bmj.com/group/rights-licensing/permissions.

BMJ Case Report Fellows may re-use this article for personal use and teaching without any further permission.

Become a Fellow of BMJ Case Reports today and you can:

- Submit as many cases as you like

- Enjoy fast sympathetic peer review and rapid publication of accepted articles

- Access all the published articles

- Re-use any of the published material for personal use and teaching without further permission

For information on Institutional Fellowships contact consortiasales@bmjgroup.com

Visit casereports.bmj.com for more articles like this and to become a Fellow 